\title{
Formaldehyde dismutase activities in Gram-positive bacteria oxidizing methanol
}

\author{
Leonid V. Bystrykh, ${ }^{\text {* }}$ Natalya I. Govorukhina, ${ }^{1}$ Peter W. van Ophem, ${ }^{2}$ Harm J. Hektor, \\ Lubbert Dijkhuizen ${ }^{1}$ and Johannis A. Durne ${ }^{2}$ \\ ${ }^{1}$ Department of Microbiology, University of Groningen, Kerklaan 30, $9751 \mathrm{NN}$ Haren, The Netherlands \\ ${ }^{2}$ Department of Microbiology and Enzymology, Delft University of Technology, Julianalaan 67, 2628 BC Delft, The \\ Netherlands
}

(Received 4 February 1993; accepted 7 April 1993)

\begin{abstract}
Extracts of methanol-grown cells of Amycolatopsis methanolica and Mycobacterium gastri oxidized methanol and ethanol with concomitant reduction of $N, N^{\prime}$-dimethyl-4-nitrosoaniline (NDMA). Anion-exchange chromatography revealed the presence of a single enzyme able to catalyse this activity in methanol- or ethanol-grown cells of $M$. gastri. A. methanolica, however, possessed two different enzymes, one of which was similar to the single enzyme found in $M$. gastri. The methanol: NDMA oxidoreductases (MNO) were purified to homogeneity from methanolgrown cells of $\boldsymbol{A}$. methanolica and $\boldsymbol{M}$. gastri. Both enzyme preparations showed similar relative molecular masses with subunits of $M_{\mathrm{r}} 50000$ and 49000 , and native enzymes of $M_{\mathrm{r}} 268000$ and 255000 (gel-filtration data for $A$. methanolica and $\boldsymbol{M}$. gastri, respectively). Both enzymes also displayed a similar substrate specificity. They were active with methanol and various other primary alcohols (yielding the corresponding aldehydes), polyols and formaldehyde. In addition, the MNO enzymes produced methylformate from methanol plus formaldehyde, and catalyzed formaldehyde dismutase and NADH-dependent formaldehyde reductase reactions. They did not possess $\mathrm{NAD}(\mathrm{P})^{+}$- or dye-linked alcohol dehydrogenase or oxidase activities.
\end{abstract}

\section{Introduction}

Gram-negative, methanol-utilizing bacteria catalyse the conversion of methanol into formaldehyde with the wellknown PQQ-containing methanol dehydrogenase (EC $1.1 .99 .8)$, which is located in the periplasmic space (Anthony, 1982; Duine et al., 1987). In contrast, the situation in the Gram-positive counterparts, which do not possess a periplasmic space, is in most cases still unresolved. In recent years, it has become clear that Gram-positive bacilli employ a novel $\mathrm{NAD}^{+}$-dependent methanol dehydrogenase, a decameric protein containing one zinc ion and one to two magnesium ions and a tightly but noncovalently bound $\mathrm{NAD}(\mathrm{H})$ cofactor per subunit (Arfman et al., 1991, 1992; Vonck et al., 1991; de Vries et al., 1992). In further studies, we have concen-

\footnotetext{
*Author for correspondence. Tel. 50 632160; fax 50632154 .

Abbreviations: MNO, methanol: NDMA oxidoreductase: PQQ, pyrroloquinoline quinone; NDMA, $N, N$-dimethyl-4-nitrosoaniline; DCPIP, dichlorophenol-indophenol; MTT, 3-(4,5-dimethylthiazol-2yl)-2,5-diphenyl-2H-tetrazolium bromide; PMS, phenazine methosulphate; n-MDH, novel (DCPIP-, NAD ${ }^{+}$-linked) methanol dehydrogenase; TD-ADH, tetrazolium dye (MTT-)dependent alcohol dehydrogenase.
}

trated on the actinomycete Amycolatopsis methanolica (De Boer et al., 1990a), previously known as Streptomyces sp. 239 (Kato et al., 1975) and Nocardia sp. 239 (Hazeu et al., 1983). In this organism, the situation with respect to methanol oxidation appears to be more complicated. Early on (Kato et al., 1975), a dye-linked methanol dehydrogenase activity, measured with DCPIP was detected in this organism. Since $\mathrm{NAD}^{+}$was shown to activate the reaction (Duine et al., 1984), it was realized that the corresponding enzyme differed significantly from the typical dye-linked PQQ-containing methanol dehydrogenase present in Gram-negative bacteria, and was therefore designated novel methanol dehydrogenase, n-MDH (Duine et al., 1984). n-MDH activity, however, could not be detected reproducibly and little progress was made in the following years. Recently, we reported an alternative and reproducible assay for detection of methanol dehydrogenase activity in $A$. methanolica employing the tetrazolium dye MTT (TD-ADH; Van Ophem et al., 1991). However, n-MDH and TD-ADH may not represent the same enzyme system since they differ in substrate specificity and only $\mathrm{n}-\mathrm{MDH}$ is activated by $\mathrm{NAD}^{+}$. The data available for $\mathrm{n}-\mathrm{MDH}$ (Duine et al., 1984) and TD-ADH (Van Ophem et al., 
1991) further indicate that these activities do not correspond to a single protein, but are part of a rather loose enzyme complex (L. V. Bystrykh, unpublished data). In the case of n-MDH, the complex may constitute an unusual methanol oxidizing enzyme with a bound $\operatorname{NAD}(\mathrm{P})^{+}$cofactor, which transfers its reducing equivalents directly to a dedicated NADH dehydrogenase (Duine et al., 1984). The same methanol oxidizing enzyme may also function within a TD-ADH enzyme complex, but most likely is associated in a different way or with alternative dye-reducing components.

In view of the above, we decided to develop an assay for the putative methanol oxidizing enzyme itself so that it could be purified and characterized. The method used here was initially designed for assaying alcohol dehydrogenases with artificially and covalently bound $\mathrm{NAD}^{+}$ (Dunn \& Bernhard, 1971; Kovár et al., 1984). The same method was also applied in the study of formaldehyde dismutase (EC 1.2.99.4), a natural example of an enzyme containing a bound $\mathrm{NAD}^{+}$, catalysing the dismutation of formaldehyde to methanol and formate (Kato et al., 1986). The above mentioned enzymes displayed alcohol dehydrogenase activity when coupling the oxidation of alcohols to reduction of a specific dye, $N, N^{\prime}$-dimethyl-4-nitrosoaniline (NDMA), but were not active with free $\mathrm{NAD}^{+}$. Based on this assay system, we found NDMA-linked alcohol oxidizing activities in methanol-grown cells of the Gram-positive bacteria $A$. methanolica and Mycobacterium gastri, but not in Corynebacterium sp. XG or Bacillus methanolicus sp. C1.

\section{Methods}

Cultivation. Amycolatopsis methanolica NCIB 11946 was grown in chemostat culture $\left(D=0.075 \mathrm{~h}^{-1}, 37^{\circ} \mathrm{C}\right.$, air supply $\left.11 \mathrm{~min}^{-1}\right)$ in a fermenter with a working volume of $1200 \mathrm{ml}$, using the 2-fold concentrated mineral medium with $2 \%(\mathrm{v} / \mathrm{v})$ methanol described previously (de Boer et al., 1990 b). Mycobacterium gastri MB19 was grown both in batch and chemostat cultures using $1 \%(\mathrm{v} / \mathrm{v})$ methanol in mineral medium (de Boer et al, 1990b) with the following modifications: $1 \mathrm{~g}$ yeast extract $1^{-1}$ and $1 \mathrm{ml}$ stock trace elements solution (Vishniac \& Santer, 1957) $\mathrm{t}^{-1}$ were added. Corynebacterium sp. XG (Bastide et al., 1989) and B. methanolicus sp. C1 (Arfman et al., 1991, 1992) were grown in batch flasks as described earlier.

Batch cultivation of the bacteria was done in Erlenmeyer flasks (total volume $500 \mathrm{ml}$ ) with $200 \mathrm{ml}$ medium at the following temperatures: $M$. gastri, Corynebacterium sp. XG, $30^{\circ} \mathrm{C} ; A$. methanolica, $37^{\circ} \mathrm{C} ; B$, methanolicus sp. $\mathrm{Cl}, 50^{\circ} \mathrm{C}$. Cells were harvested at the end of the exponential growth phase.

Preparation of cell-free extracts. Cells were harvested by centrifugation for $10 \mathrm{~min}$ at $18000 \mathrm{~g}\left(r_{\mathrm{av}} 6.98 \mathrm{~cm}\right), 4^{\circ} \mathrm{C}$, washed once with $0 \cdot 1 \mathrm{M}$-potassium phosphate buffer, $\mathrm{pH} 7 \cdot 0$, repeatedly centrifuged and stored frozen at $-75^{\circ} \mathrm{C}$. Crude extracts were prepared by resuspension of freshly harvested or frozen cells in the buffer mentioned above $(2 \mathrm{ml}$ per $\mathrm{g}$ of cells), then disintegrated by passage (three to five times) through a French pressure cell, $4^{\circ} \mathrm{C}, 1.5 \times 10^{5} \mathrm{kN} \mathrm{m}^{-2}$. The homogenate was centrifuged at $4^{\circ} \mathrm{C}, 25000 \mathrm{~g}\left(r_{\mathrm{av}} 6.98 \mathrm{~cm}\right), 30 \mathrm{~min}$. Crude extract was used for enzyme assays and enzyme purification.
Enzyme assays. Methanol:NDMA oxidoreductase (MNO) activity was assayed in a double beam recording spectrophotometer (Hitachi $100-60$ ) at $30^{\circ} \mathrm{C}$, using the following mixture: potassium phosphate buffer, pH 6.3, 0.1 M; NDMA, 0.01 mM; methanol, $25 \mathrm{~mm}$; enzyme preparation. The assay was performed at $440 \mathrm{~nm}$ and the molar extinction coefficient of NDMA was taken as $35400 \mathrm{M}^{-1} \mathrm{~cm}^{-1}$ (Dunn \& Bernhard, 1971). The reaction was started by addition of methanol. Ethanol : NDMA oxidoreductase reaction was assayed as above except that $20 \mathrm{~mm}$-ethanol was used instead of methanol. Formaldehyde dismutase activity was assayed in a $5 \mathrm{ml}$ working volume, at $30^{\circ} \mathrm{C}, \mathrm{pH}$ 6.3 , by following formic acid production using a $\mathrm{pH}$-stat as described by Kato et al. (1983). The reaction was started by addition of $20 \mathrm{~mm}-$ formaldehyde. Formaldehyde reductase activity was measured spectrophotometrically by following the oxidation of $\mathrm{NADH}$ at $340 \mathrm{~nm}$. The assay mixture ( $1 \mathrm{ml}$ ) contained: $0 \cdot 1 \mathrm{M}$-potassium phosphate buffer, $\mathrm{pH}$ $5.0 ; \mathrm{NADH}, 0.2 \mathrm{~mm}$; enzyme preparation. The reaction was started by addition of $0.2 \mathrm{mM}$-formaldehyde. $\mathrm{NAD}^{+}$- or $\mathrm{NAD}^{+} / \mathrm{DCPIP}$-dependent alcohol dehydrogenase activities were assayed with methanol or ethanol as described earlier (Duine $e t a l ., 1984$ ). One unit of the enzyme activity corresponds to the conversion of $1 \mu \mathrm{mol}$ of substrate $\mathrm{min}^{-1}$.

Enzyme purification. Purification of the MNO enzymes from both $A$. methanolica and $M$. gastri was performed via a two-step FPLC procedure. Crude extract prepared from $3 \mathrm{~g}$ of frozen cells was applied on a Q-Sepharose column $(1 \times 10 \mathrm{~cm})$ (Pharmacia) in $0.1 \mathrm{M}$-potassium phosphate buffer $\mathrm{pH} 7 \cdot 5$. A gradient of $\mathrm{KCl}(0-1 \mathrm{M})$ was applied at a flow rate of $0.5 \mathrm{ml} \mathrm{min} \mathrm{m}^{-1}$ over a period of $1 \mathrm{~h}$. Active fractions were

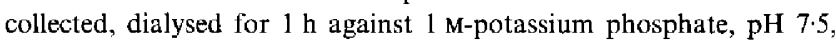
then applied onto a phenyl-Superose HR 5/5 column, equilibrated with the same buffer as used for dialysis. Finally, the enzyme was eluted in a gradient (1-0.05 $\mathrm{M}, \mathrm{pH} 7.5)$ of potassium phosphate, over a period of $30 \mathrm{~min}$ at a flow rate of $0.5 \mathrm{ml} \mathrm{min}-1$. Active fractions were pooled and stored frozen at $-80^{\circ} \mathrm{C}$.

Estimation of kinetic constants. In most cases the single-substrate Michaelis-Menten equation (with competitive substrate inhibition if detected) was applied to calculate apparent $V_{\max }, K_{\mathrm{m}}$ and $K_{\mathrm{i}}$ values. Concentrations of the second substrates were kept constant as described under enzyme assays. For comparison a two-substrate ping-pong-type equation with competitive inhibition by both substrates was used to estimate true kinetic constants. Fitting of the experimental data was achieved via linear regression analysis using primary plots of reaction rates versus substrate concentrations.

Relative molecular mass estimation. The relative molecular masses of the purified native enzymes were estimated by gel-filtration chromatography using a calibrated Superose 12 HR 10/30 column. A calibration curve was prepared with thyroglobulin $\left(M_{\mathrm{r}} 670000\right)$ gamma globulin $\left(M_{\mathrm{r}} 158000\right)$, ovalbumin $\left(M_{\mathrm{r}} 44000\right)$ and myoglobin $\left(M_{\mathrm{r}}\right.$ 17000).

Assay of methylformate. MNO enzyme samples were incubated with $40 \mathrm{~mm}$-methanol and $40 \mathrm{~mm}$-formaldehyde at $20^{\circ} \mathrm{C}$ for $1 \mathrm{~h}$ in $10 \mathrm{~mm}$ potassium phosphate buffer, $\mathrm{pH} 7 \cdot 0$, in a final volume of $1 \mathrm{ml}$. The assay mixture was filtered through a membrane with a cut + off of $10 \mathrm{kDa} ; 1 \mu \mathrm{l}$ of the filtrate was applied onto a HP-l column (crosslinked methyl-silicone; $30 \mathrm{~m} \times 0.53 \mathrm{~mm}$; layer thickness $2.65 \mu \mathrm{m}$ ) attached to a Hewlett-Packard HP 5890 series II gas chromatograph. Injector, column and detector temperatures were 250,40 and $250^{\circ} \mathrm{C}$, respectively. A flame ionization detector was used for the assay.

Electrophoresis. Denaturing polyacrylamide (12\%) gel electrophoresis (SDS-PAGE; Laemmli \& Favre, 1973) was performed in combination with a PhastSystem electrophoresis unit (PharmaciaLKB). The following prestained protein markers (Sigma, USA) were used: $\alpha_{2}$-macroglobulin $\left(M_{\mathrm{r}} 180000\right), \beta$-galactosidase $\left(M_{\mathrm{r}} 116000\right)$, fructose-6-phosphate kinase $\left(M_{\mathrm{r}} 84000\right)$, pyruvate kinase $\left(M_{\mathrm{r}} 58000\right)$, fumarase $\left(M_{\mathrm{r}} 48500\right)$, lactic acid dehydrogenase $\left(M_{\mathrm{r}} 36500\right)$, trio- 
Table 1. Methanol:NDMA and ethanol:NDMA oxidoreductase activities in crude extracts of A. methanolica and $M$. gastri cells grown in batch flasks with different substrates

\begin{tabular}{|c|c|c|c|c|c|}
\hline \multirow{3}{*}{$\begin{array}{l}\text { Growth } \\
\text { substrate } \\
(1 \%, w / v \\
\text { final concr) }\end{array}$} & \multirow[b]{3}{*}{ Tested with ... } & \multicolumn{4}{|c|}{ Specific activities $\left(\mathrm{mU} \mathrm{mg}^{-1}\right)$ of extracts } \\
\hline & & \multicolumn{2}{|c|}{ A. methanolica } & \multicolumn{2}{|c|}{ M. gastri } \\
\hline & & Methanol & Ethanol & Methanol & Ethanol \\
\hline Methanol & & 3 & 5 & 9 & 12 \\
\hline Ethanol & & 3 & 4 & 0 & 0 \\
\hline Propan-1-ol & & 1 & 6 & 16 & 37 \\
\hline Propan-2-ol & & NG & NG & 12 & 12 \\
\hline Butanol & & 2 & 1 & 0 & 0 \\
\hline Ethyleneglycol & & NG & NG & 0 & 0 \\
\hline Glycerol & & 0 & 0 & 28 & 23 \\
\hline Glucose & & 0 & 0 & 0 & 0 \\
\hline
\end{tabular}

NG, No growth.

sephosphate isomerase $\left(M_{\mathrm{r}} 26600\right)$. Gels were stained for protein with Coomassie brilliant blue G-250.

Protein concentration. Protein concentration was measured by using the direct spectrophotometric assay (Kalb \& Bernlohr, 1977) or the Bio-Rad protein assay (Bradford method) using BSA (Bio-Rad) for a calibration curve.

\section{Results}

Detection of alcohol: NDMA oxidoreductase activities in crude extracts of Gram-positive bacteria

Reduction of NDMA coupled to oxidation of methanol and ethanol was detected in crude extracts of Amycolatopsis methanolica and Mycobacterium gastri cells grown on various substrates (Table 1). No NDMAdependent alcohol-oxidizing activities were found in cells (methanol-grown) of Corynebacterium sp. XG, or $B$. methanolicus sp. $\mathrm{Cl}$. The specific alcohol: NDMA oxidoreductase activities detected were relatively low but could be measured reproducibly mainly because of the high molar extinction coefficient of NDMA. Methanol and ethanol: NDMA oxidoreductase activities were detected only in cells of $A$. methanolica, grown on primary alcohols (Table 1). A different and more complicated pattern was observed with $M$. gastri. NDMA-dependent alcohol oxidizing activities could be detected in cells grown on, for instance, methanol or glycerol but not with ethanol or butanol.

Unlike the situation in methylotrophic bacilli (Arfman et al., 1991), only trace activities of an $\mathrm{NAD}^{+}$-dependent methanol dehydrogenase were detected in methanolor ethanol-grown cells of $A$. methanolica and $M$. gastri $(<1 \mathrm{mU} \mathrm{mg} \mathrm{l})$. Transition from methanol- to ethanolcontaining medium caused induction of $\mathrm{NAD}^{+}$-dependent ethanol dehydrogenase activities, increasing from less than $1 \mathrm{mU} \mathrm{mg}^{-1}$ to 20 and $200 \mathrm{mU} \mathrm{mg}^{-1}$ in $A$. methanolica and $M$. gastri, respectively. At the same time the NDMA-dependent ethanol oxidizing activities decreased in $M$. gastri (Table 1). These results may be taken to suggest that $A$. methanolica and $M$. gastri employ $\mathrm{NAD}^{+}$-dependent alcohol dehydrogenases for ethanol oxidation, but not for methanol oxidation. We therefore decided to study the methanol: NDMA oxidoreductases in these organisms in more detail.

\section{FPLC analysis of NDMA-linked alcohol oxidizing activities}

Fractionation of crude extracts of methanol-limited chemostat-grown cells of $A$. methanolica on a QSepharose column revealed the presence of two proteins active with NDMA and alcohols. One of these was active with both methanol and ethanol, whereas the other one was specific for ethanol (Van Ophem et al., 1993). In cells of $M$. gastri grown on methanol, only one enzyme was found, catalysing both NDMA-linked ethanol- and methanol-oxidizing reactions. However, when the strain was grown on propan-1-ol, FPLC analysis indicated the presence of an additional protein active with ethanol but not with methanol. This protein eluted at the same position as the ethanol: NDMA oxidizing enzyme from A. methanolica. None of these fractions contained any $\mathrm{NAD}^{+}$-dependent alcohol dehydrogenase activity.

A further purification step on phenyl-Superose yielded homogeneous preparations of the NDMA-linked methanol oxidizing enzymes from both $A$. methanolica and $M$. gastri (Table 2). This is the first instance of the purification to homogeneity of an enzyme of $A$. methanolica with methanol-oxidizing activity, proving its existence as an individual protein. At present, NDMA is the only known artificial electron acceptor for methanol oxidation by both these enzymes: no methanol oxidizing 
Table 2. Purification of methanol:NDMA oxidoreductases from A. methanolica and $M$. gastri

\begin{tabular}{lccccc}
\hline \multicolumn{1}{c}{ Step } & $\begin{array}{c}\text { Protein } \\
\left(\mathrm{mg} \mathrm{ml}^{-1}\right)\end{array}$ & $\begin{array}{c}\text { Specific } \\
\text { activity } \\
\left(\mathrm{mU} \mathrm{mg}^{-1}\right)\end{array}$ & $\begin{array}{c}\text { Total } \\
\text { activity } \\
(\mathrm{mU})\end{array}$ & $\begin{array}{c}\text { Yield } \\
(\%)\end{array}$ & $\begin{array}{c}\text { Purifi- } \\
\text { cation } \\
(\text {-fold })\end{array}$ \\
\hline $\begin{array}{l}\text { (a) } \text { A. methanolica } \\
\text { 1. Crude extract }\end{array}$ & $15 \cdot 9$ & 7 & 457 & 100 & 1 \\
2. Q-Sepharose & $0 \cdot 3$ & 61 & 158 & 35 & $9 \cdot 1$ \\
3. Phenyl-Superose & $0 \cdot 2$ & 73 & 68 & 15 & $10 \cdot 9$ \\
(b) M. gastri & & & & & \\
1. Crude extract & 3.5 & 28 & 1943 & 100 & 1 \\
2. Q-Sepharose & 1.5 & 60 & 1479 & 76 & $2 \cdot 1$ \\
3. Phenyl-Superose & $2 \cdot 8$ & 96 & 1352 & 68 & $3 \cdot 4$ \\
\hline \hline
\end{tabular}

activity was observed with pyridine dinucleotides and with common artificial electron acceptors such as PMS, PMS/DCPIP and tetrazolium salts. The in vivo electron acceptor for these enzymes remains to be identified.

\section{Relative molecular mass and quaternary structure of $M N O$}

The relative molecular masses of the purified native MNO enzymes from $A$. methanolica and $M$. gastri, as studied by gel-filtration chromatography, were estimated as $M_{\mathrm{r}} 268000$ and $M_{\mathrm{r}} 255000$, respectively. SDS gel electrophoresis revealed the presence of a single subunit species in both enzyme preparations, with estimated subunit relative molecular masses of $M_{\mathrm{r}} 50000$ and $M_{\mathrm{r}}$ 49000 for the enzymes from $A$. methanolica and $M$. gastri, respectively. Both the native enzymes thus might contain four or five identical subunits. However, electron microscopic studies have revealed that both enzymes have decameric structures (Bystrykh et al., 1993), similar to the $\mathrm{NAD}^{+}$-dependent methanol dehydrogenase in $B$. methanolicus sp. C1 (Vonck et al,, 1991). These three enzymes also show a high degree of similarity in their primary amino acid sequences (Bystrykh et al., 1993).

\section{Catalytic properties}

Both purified MNO enzymes are able to catalyse three reactions: NDMA-coupled oxidation of methanol, dismutation of formaldehyde to methanol and formic acid, and NADH-dependent reduction of formaldehyde. Reduction of NDMA could also be coupled to oxidation of NADH. The ability of MNO to catalyse NDMA-linked reactions as well as the formaldehyde dismutase activity strongly suggested the presence of a bound pyridine dinucleotide (Dunn \& Bernhard, 1971; Kato et al., 1986). Further studies revealed the presence of tightly but noncovalently bound NADPH (Bystrykh et al., 1993).

When preparations of MNO from both $A$. methanolica and $M$. gastri were incubated with equal amounts of methanol and formaldehyde, a product with the same retention time as methylformate was detected by gas chromatographic analysis. The methylformate, however, partially hydrolysed under the assay conditions used, interfering with attempts to measure the stoichiometry of the reaction.

\section{Effects of $p H$, temperature, and protein concentration}

The $\mathrm{pH}$ optima for the methanol:NDMA oxidoreductase and formaldehyde dismutase reactions catalysed by both MNO preparations are comparable, namely $\mathrm{pH} 6 \cdot 3$. The formaldehyde reductase reaction displayed a lower $\mathrm{pH}$ optimum, namely $\mathrm{pH} 4 \cdot 5-5 \cdot 0$.

MNO enzyme activity increased with temperature up to $55^{\circ} \mathrm{C}$. Above this temperature, both enzymes inactivated within a few min. Both enzymes remained completely stable during incubation for $1 \mathrm{~h}$ at $30^{\circ} \mathrm{C}$ and $\mathrm{pH} 6.3$.

Plots of the methanol: NDMA oxidoreductase (Fig. 1) and formaldehyde reductase activities of the purified MNO enzymes versus protein concentration are not linear. Fixed protein concentrations (about $20 \mu \mathrm{g}$ of protein per $\mathrm{ml}$ of assay mixture) were therefore used for the further kinetic analysis of these enzymes.

\section{Inhibitors}

Addition of azide and hydrazine (final concentrations of $1 \mathrm{~mm}$ ) to the assay mixture completely inhibited the $A$. methanolica MNO activity. Pyrazol (1 mM) caused $59 \%$ inhibition. EDTA, $\mathrm{Mg}^{2+}$, DTT and mercaptoethanol used at the same concentrations had no effect. Similar results were obtained with the formaldehyde dismutase assay, except that EDTA caused complete inhibition and pyrazol did not inhibit.

\section{Kinetics of NDMA-linked oxidation of alcohols}

The MNO enzymes from both $A$. methanolica and $M$. gastri showed a high affinity for NDMA. The alcohol: 


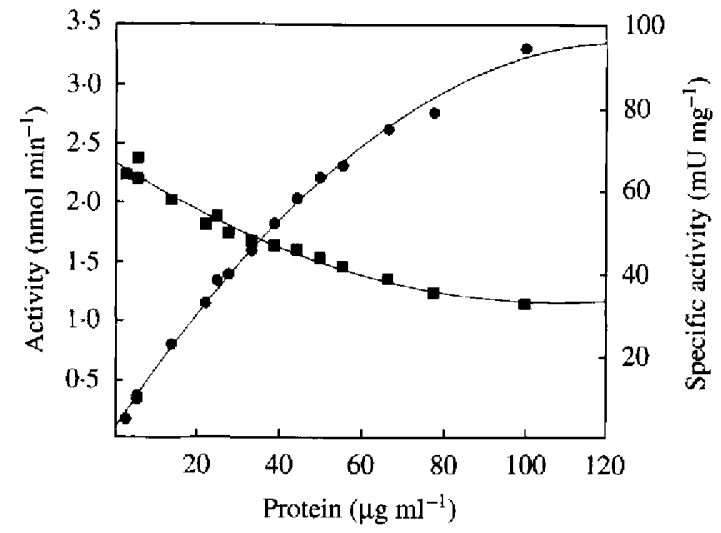

Fig. 1. Effect of MNO protein (from $M$. gastri) concentrations on methanol: NDMA oxidoreductase activities. $\mathbf{\square}$, Specific activity;

- total activity.

NDMA oxidoreductase reaction obeyed MichaelisMenten kinetics. The substrate specificity of both enzymes to alcohol substrates was very broad (Table 3 ). Methanol, glycerol and ethyleneglycol did not inhibit the enzymes, whereas most of the other substrates did. The kinetics of NDMA-linked oxidation of methanol was found to obey a ping-pong mechanism (Fig. 2). Comparison of the apparent kinetic parameters for primary alcohols with the true parameters revealed insignificant differences, suggesting that the apparent kinetic parameters in Table 3 are very close to the true ones.

\section{Formaldehyde reductase reaction}

When using the formaldehyde reductase assay, activity was found with NADH but not with NADPH as an electron donor. Both enzymes were active with all

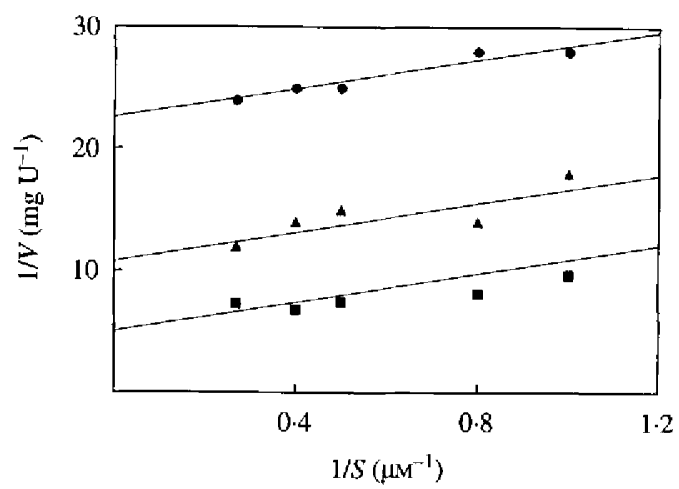

Fig. 2. Double reciprocal plots of methanol: NDMA oxidoreductase activity of MNO from $A$. methanolica. Concentrations of NDMA: $12 \mu \mathrm{M}(\boldsymbol{O}) ; 28 \mu \mathrm{M}(\mathbf{A}) ; 42 \mu \mathrm{M}(\mathbf{\square})$

primary aldehydes tested with a carbon-chain length from $\mathrm{C}_{1}$ to at least $\mathrm{C}_{4}$ (Table 4). However, the progress curve of the reaction became increasingly nonlinear with increasing carbon-chain length of the aldehyde substrate. Affinity for the substrates decreased so dramatically, that saturation of the enzyme by substrate could not be attained. Finally, the enzyme gradually deviated from Michaelis- Menten function with increasing carbonchain length of the substrate.

\section{Formaldehyde dismutase reaction}

Plots of the formaldehyde dismutase activities of MNO from A. methanolica and $M$. gastri versus protein concentration were linear. The formaldehyde dismutase reaction obeyed Michaelis-Menten kinetics with respect to formaldehyde. No activity was found with acetaldehyde, propionaldehyde or butyraldehyde. The $K_{\mathrm{m}}$

Table 3. Substrate specificities of the methanol: NDMA oxidoreductases from A. methanolica and $M$. gastri

\begin{tabular}{|c|c|c|c|c|c|c|}
\hline \multirow[b]{2}{*}{ Substrate } & \multicolumn{3}{|c|}{ A. methanolica } & \multicolumn{3}{|c|}{ M. gastri } \\
\hline & $\left(\mathrm{mU} \max ^{\prime} \mathrm{mg}^{-1}\right)$ & $\begin{array}{l}K_{\mathrm{m}}^{\prime *} \\
(\mathrm{mM})\end{array}$ & $\begin{array}{c}K_{\mathrm{i}}^{\prime} \\
(\mathrm{mM})\end{array}$ & $\begin{array}{c}V_{\max }^{\prime} \\
\left(\mathrm{mU} \mathrm{mg}^{-1}\right)\end{array}$ & $\begin{array}{c}K_{\mathrm{mm}}^{\prime *} \\
(\mathrm{mM})\end{array}$ & $\begin{array}{c}K_{\mathrm{i}}^{\prime} \\
(\mathrm{mM})\end{array}$ \\
\hline NDMA (+methanol) & 65 & $0 \cdot 018$ & $\infty$ & 162 & $0 \cdot 023$ & $\infty$ \\
\hline Methanol & 57 & 2.65 & $\infty$ & $79 \cdot 2$ & $3 \cdot 4$ & $\infty$ \\
\hline Ethanol & 90 & $0-057$ & $165 \cdot 6$ & 82 & $0 \cdot 003$ & $14 \cdot 6$ \\
\hline Propanol & 77 & 0.002 & 104 & 199 & 0.001 & $46+4$ \\
\hline Butanol & 76 & 0.002 & $20 \cdot 1$ & 154 & $0-001$ & $43 \cdot 8$ \\
\hline Propan-2-ol & 73 & $0 \cdot 110$ & $29 \cdot 7$ & 73 & 0.071 & $255 \cdot 0$ \\
\hline Isobutanol & 73 & $0-001$ & $36 \cdot 9$ & 72 & $0-001$ & $181 \cdot 2$ \\
\hline 2-Methoxyethanol & 63 & 0.010 & 12 & 66 & 0.58 & $39 \cdot 8$ \\
\hline Formaldehyde & 51 & 0.007 & 1.5 & $75 \cdot 8$ & $0 \cdot 29$ & $82 \cdot 8$ \\
\hline Ethyleneglycol & 66 & 0.047 & $\infty$ & $167 \cdot 6$ & 0.85 & $\infty$ \\
\hline Glycerol & 72 & 0.970 & $\infty$ & 146.4 & $8 \cdot 04$ & $\infty$ \\
\hline Ethanolamine & 40 & $17 \cdot 0$ & 220 & 28 & 40 & $\infty$ \\
\hline
\end{tabular}

$\infty$, No inhibition.

* The limit of the $K_{\mathrm{m}}$ measurement was $0.001 \mathrm{~mm}$. 
Table 4. Aldehyde reductase (NADH-dependent) and formaldehyde dismutase reactions catalysed by the methanol: NDMA oxidoreductases from $A$. methanolica and $M$. gastri

\begin{tabular}{|c|c|c|c|c|}
\hline \multirow[b]{2}{*}{ Substrate } & \multicolumn{2}{|c|}{ A. methanolica } & \multicolumn{2}{|c|}{ M. gastri } \\
\hline & $\begin{array}{c}V_{\max }^{\prime} \\
\left(\mathrm{m} \mathrm{mg}^{-1}\right)\end{array}$ & $\underset{(\mathrm{mM})}{K_{\mathrm{m}}^{\prime}}$ & $\underset{\left(m U^{\prime} \mathrm{mg}^{-1}\right)}{V^{\prime}}$ & $\begin{array}{c}K_{\mathrm{m}}^{\prime} \\
(\mathrm{mM})\end{array}$ \\
\hline \multicolumn{5}{|c|}{ Aldehyde reductase reaction } \\
\hline $\mathrm{NADH}$ (with $\mathrm{CH}_{2} \mathrm{O}$ ) & 100 & 0.6 & $19 \cdot 8$ & 0.07 \\
\hline Formaldehyde & 14 & 0.01 & $14 \cdot 5$ & $0-26$ \\
\hline Acetaldehyde & 15 & 0.7 & $90 \cdot 5$ & $35 \cdot 5$ \\
\hline Propionaldehyde & 72 & 246 & 71 & 68 \\
\hline Butyraldehyde & - & - & 50 & 75 \\
\hline \multicolumn{5}{|c|}{ Formaldehyde dismutase reaction } \\
\hline Formaldehyde & 85000 & $19 \cdot 5$ & 132000 & $12 \cdot 4$ \\
\hline
\end{tabular}

value obtained for formaldehyde was rather high in this reaction, compared to the values obtained for the NDMA- or NADH-dependent activities mentioned above. However, the $V_{\max }$ of the formaldehyde dismutase reaction was hundreds of times higher than the values obtained for the formaldehyde oxidizing and formaldehyde reducing reactions measured with NDMA and $\mathrm{NADH}$, respectively. Clearly, the large differences in $V_{\max }$ and $K_{\mathrm{m}}$ values for formaldehyde in these reactions must be a reflection of different rate limiting steps in the reaction cycles.

\section{Discussion}

The results presented show that several Gram-positive bacteria able to oxidize methanol ( $A$. methanolica, $M$. gastri) contain a highly active formaldehyde dismutase. The enzymes studied also display alcohol:NDMA oxidoreductase activity with a very broad substrate specificity towards methanol (albeit with a poor affinity) and various other primary alcohols, and formaldehyde. Both these MNO enzymes possess a firmly bound pyridine dinucleotide (NADPH) cofactor which is catalytically active (Bystrykh et al., 1993). The kinetics of this type of enzyme is generally of the ping-pong type (Kováí et al., 1984; Kato et al., 1986; Frey, 1987), as was shown to be the case for MNO (Fig. 2).

From the various reactions catalysed by MNO, the highest activity by far was observed with the formaldehyde dismutase assay (compare Tables 3 and 4). This may reflect the fact that neither NDMA (in the methanol: NDMA oxidoreductase reaction) nor NADH (in the aldehyde reductase reaction) are physiological substrates for the MNO enzymes. The information currently available for other oxidoreductases with tightly bound pyridine nucleotide cofactors, such as glucosefructose oxidoreductase from Zymomonas mobilis (Zachariou \& Scopes, 1984), lactate-oxaloacetate trans- hydrogenase from Veillonella alcalescens (Allen, 1966, 1982) and formaldehyde dismutase from Pseudomonas putida (Kato et al., 1986), shows that under physiological conditions these enzymes also do not use free pyridine dinucleotides as substrates.

The MNO enzymes and formaldehyde dismutase from $P$. putida share the ability to catalyse the NDMA-linked oxidation of alcohols, and to dismutate formaldehyde (Kato et al., 1986). A further comparison of properties, however, reveals significant differences between these enzymes as well. $P$. putida $\mathrm{F} 61$ is a non-methylotrophic formaldehyde-resistant strain. In this organism, formaldehyde dismutase functions as a formaldehyde detoxifying enzyme, the synthesis of which is induced by addition of formaldehyde to the medium. This enables $P$. putida to resist formaldehyde concentrations up to $60 \mathrm{~mm}$ (Kato et al., 1983). Unlike P. putida, both $A$. methanolica and $M$. gastri are methylotrophic bacteria and still sensitive to formaldehyde. A. methanolica is unable to tolerate formaldehyde levels above $0.8 \mathrm{~mm}$ (de Boer $e t$ al., 1990 b). Moreover, when gradually increasing the methanol concentration in the feed of a chemostat culture of A. methanolica, we observed formaldehyde accumulation in the culture and a decrease in MNO activity (data not shown). It thus appears doubtful that MNO fulfils the same in vivo function as formaldehyde dismutase from $P$. putida. Further differences are that the $P$. putida formaldehyde dismutase (tetramer with subunits of $M_{\mathrm{r}} 55000$ ) does not display methanol: NDMA oxidoreductase activity, unlike the MNO enzymes (decamers with subunits of $M_{\mathrm{r}} 49-50000$ ) from $A$. methanolica and $M$. gastri. The prosthetic groups of these enzymes are also different, with NADPH in MNO (Bystrykh et al., 1993) and NADH in formaldehyde dismutase (Kato et al., 1986). No similarity is apparent between the $\mathrm{N}$-terminal amino acid sequences of formaldehyde dismutase of $P$. putida (N. Kato, personal communication) and the MNO enzymes (Bystrykh et al., 1993). Instead, amino acid sequencing data and computer image analysis revealed rather strong similarities between the MNO enzymes and methanol dehydrogenase from Bacillus methanolicus sp. $\mathrm{C} 1$ (Vonck et al., 1991; Bystrykh et al., 1993). All three enzymes appear to belong to a recently established third family of alcohol dehydrogenases (Bystrykh et al., 1993; de Vries et al., 1992). The Bacillus methanol dehydrogenase is the enzyme responsible for methanol oxidation in this Grampositive bacterium. It thus appears likely that the MNO enzymes have a similar function in the Gram-positive bacteria $A$. methanolica and $M$. gastri. Recently, we have been able to isolate a number of methanol-negative mutants of $A$. methanolica and the various classes are being further characterized at the moment. Nevertheless, it is already clear that mutants blocked in MNO have 
completely lost the ability to oxidize methanol and no longer grow with methanol as sole carbon and energy source. Further work is certainly required to elucidate the full in vivo role of the MNO enzymes. The enzyme in $A$. methanolica may be an essential component of a multi-enzyme methanol dehydrogenase complex, resulting in the n-MDH or TD-ADH activities reported earlier (Duine et al., 1984; van Ophem et al., 1991).

\section{References}

Allen, S. H. G. (1966). The isolation and characterization of malatelactate transhydrogenase from Micrococcus lactilyticus. Journal of Biological Chemistry 241, 5266-5275.

Allex, S. H. G. (1982). Lactate-oxaloacetate transhydrogenase from Veillonella alcalescens. Methods in Enzymology 89, 367-376.

AnthoNy, C. (1982). The Biochemistry of Methylotrophs, pp. 176-177. London: Academic Press.

Arfman, N., Van Beeumen, J., De Vries, G. E., Harder, W. \& Dijkhuizen, L. (1991). Purification and characterization of an activator protein for methanol dehydrogenase from thermotolerant Bacillus spp. Journal of Biological Chemistry 266, 3955-3960.

Arfman, N., Dijkhuizen, L., Kirchhof, G., Ludwig, W., Schleifer, K. H., Bulygina, E. S., Chumakov, K. M., Govorukhina, N. I., Trotsenko, Yu.A., White, D. \& Sharp, R. J. (1992). Bacillus methanolicus sp. nov., a new species of thermotolerant, methanolutilizing, endospore-forming bacteria. International Journal of Systematic Bacteriology 42, 439-445.

Bastide, A., Lager, M., PAtte, J.-C. \& Dumentl, G. (1989). Methanol metabolism in Corynebacterium sp. XG, a facultatively methylotrophic strain. Journal of General Microbiology 135, 2869-2874.

de Boer, L., Dijkhuizen, L., Grobben, G., Goodfellow, M., Stackebrandt, E., Parlett, J. H., Wintehead, D. \& Witt, D. (1990a). Amycolatopsis methanolica sp. nov., a facultatively methylotrophic actinomycete. International Journal of Systematic Bacteriology 40, 194-204.

de Boer, L., Euverink, G. J., van der Vlag, J. \& Dijkhulzen, L. $(1990 \mathrm{~b})$. Regulation of methanol metabolism in the facultative methylotroph Nocardia sp. 239 during growth on mixed substrates in batch- and continuous cultures. Archives of Microbiology 153, 337-343.

BySTRYKH, L. V., VONCK, J., VAN BRUGGEN, E. F. J., VAN BEEUMEN, J., Samyn, B., Govorukhina, N. I., Arfman, N., Duine, J. A. \& DuJkHUizeN, L. (1993). Electron microscopic analysis and structural characterization of novel NADP(H)-containing methanol:NDMA oxidoreductases from the Gram-positive methylotrophic bacteria Amycolatopsis methanolica and Mycobacterium gastri MB19. Journal of Bacteriology 175, 1814-1822.

DuINe J. A., Frank J. \& Berkhout M. P. J. (1984). NAD-dependent, PQQ-containing methanol dehydrogenase: a bacterial dehydrogenase in multienzyme complex. FEBS Letters 168, 217-221.
Dutne J. A., Frank J. \& Dijkstra, M. (1987). Quinoproteins in the dissimilation of $\mathrm{C}_{1}$ compounds. In Proceedings of the 5 th $\mathrm{In}$ ternational Symposium Microbial Growth on $C_{1}$ Compounds, pp. 105-112. Edited by H. W. van Verseveld \& J. A. Duine. Dordrecht: Martinus Nijhof.

Dunn, M. F. \& Bernhard, S. A. (1971). Rapid kinetic evidence for adduct formation between the substrate analog $p$-nitroso- $N, N$ dimethyl-aniline and reduced nicotinamide dinucleotide during enzymatic reduction. Biochemistry 10, 4569-4575.

FreY, P. A. (1987). Complex pyridine nucleotide-dependent transformations. In Pyridine Nucleotide Coenzymes, pp. 461-511. Edited by D. Dolphin, O. Avramović \& R. Poulson. New York: John Wiley \& Sons.

Hazeu, W., de Bruyn, J. C. \& van Duken, J. P. (1983). Nocardia sp. 239 , a facultative methanol utilizer with the ribulose monophosphate pathway of formaldehyde fixation. Archives of Microbiology 135 , 205-210.

KALB, V.F. \& BERNLOHR, R. W. (1977) A new spectrophotometric assay for protein in cell extracts. Analytical Biochemistry 82, 362-371.

Kato, N., Tsur, K., TaNi, Y. \& OGata, K. (1975). Utilization of methanol by an actinomycete. In Proceedings of the 1st International Symposium Microbial Growth on $C_{1}$ Compounds, pp. 91-97, Tokyo.

Kato, N., Sinirakawa, K., Kobayashi, H. \& Sakazawa C. (1983). The dismutation of aldehydes by a bacterial enzyme. Agricultural and Biological Chemistry 47, 39-46.

Kato, N., Yamagami, T., Shimao, M. \& Sakazawa C. (1986). Formaldehyde dismutase, a novel NAD-binding oxidoreductase from Pseudomonas putida F61. European Journal of Biochemistry 156, 59-64.

Kovár̆, J., S̆ImeK, K., KuČera, I. \& MATYSKA, L. (1984). Steady-state kinetics of horse-liver alcohol dehydrogenase with a covalently bound coenzyme analogue. European Journal of Biochemistry 139, 585-591.

LaEmMLI, U. K. \& FAVRE, K. (1973). Maturation of the head of bacteriophage T4. I. DNA packaging events. Journal of Molecular Biology 80, 575-599.

van Ophem, P. W., Euverink, G.-J., Dujkhuizen, L. \& Duine, J. A. (1991). A novel dye-linked alcohol dehydrogenase activity present in some Gram-positive bacteria. FEMS Microbiology Letters 80, 57-64.

van Ophem, P. W., van Beeumen, J., Duine, J. A. (1993). Nicotinoprotein [NAD(P)-containing] alcohol/aldehyde oxidoreductases: purification and characterization of a novel type from Amycolatopsis methanolica. European Journal of Biochemistry 212, 819-826.

VishniaC, W. \& Santer, M. (1957). The thiobacilli. Bacteriological Reviews 21, 195-213.

Vonck, J., Arfman, N., de VRIEs, G. E., VAN BeElmen J., VAN Bruggen E. F. J. \& Dukhuizen, L. (1991). Electron microscopic analysis and biochemical characterization of a novel methanol dehydrogenase from the thermotolerant Bacillus sp. C1. Journal of Biological Chemistry 266, $3949-3954$.

de Vries, G. E., Arfman, N., Terpstra, P. \& Dukhuizen, L. (1992). Cloning, expression, and sequence analysis of the Bacillus methanolicus $\mathrm{C} 1$ methanol dehydrogenase gene. Joumal of Bacteriology 174, $5346-5353$.

ZaChariou, M. \& SCOPES, R. K. (1986). Glucose-fructose oxidoreductase, a new enzyme isolated from Zymomonas mobilis that is responsible for sorbitol production. Journal of Bacteriology 167 , $863-869$. 